\title{
PROTECTIVE EFFECTS OF Solanium nigrum METHANOLIC EXTRACT AGAINST ISONIAZID/RIFAMPICIN INDUCED HEPATOTOXICITY IN RATS
}

\author{
Abdel-Hameed M.Fayed ${ }^{1}$; Abeer A. A. Salama ${ }^{1}$; Ismaiel E Ismaiel ${ }^{1}$; Taha A. Attia ${ }^{2}$; \\ Elbatran Seham $A^{1}$ and Azza Hassan ${ }^{3}$ \\ ${ }^{1}$ Pharmacology Department National Research Centre, Giza, Egypt \\ ${ }^{2}$ Pharmacology Department, Faculty of Vet. Med., El-Sadat University, Minoufiya, Egypt \\ ${ }^{3}$ Pathology Department, Faculty of Vet. Med., Cairo University, Giza, Egypt \\ * Corresponding author: Abdel-Hameed M.Fayed; email; fayed.nrc@gmail.com
}

\begin{abstract}
Drug-induced liver injury (DILI) is the major health problem that resulted from uses of many drugs especially from serious adverse effect of antituberculosis (ATT) drugs. forty eight rats $(200-250 \mathrm{~g})$ were allocated into six groups (8 rats in each group), and treated as follow: group I: received normal saline orally; group II: received INH/RFP (50 mg/Kg/day of each) for 28 days orally; group III: received Silymarin $(50 \mathrm{mg} / \mathrm{kg} /$ day $)+\mathrm{INH} / \mathrm{RFP}$ for 28 days orally; group IV: received SNME $(250 \mathrm{mg} / \mathrm{Kg} /$ day $)+\mathrm{INH} / \mathrm{RFP}$ for 28 days orally; group V: received SNME $(500 \mathrm{mg} / \mathrm{Kg} /$ day $)+\mathrm{INH} / \mathrm{RFP}$ for 28 days orally; group VI, received SNME (1000 $\mathrm{mg} / \mathrm{Kg} /$ day) $+\mathrm{INH} / \mathrm{RFP}$ for 28 days orally. Co-administration of herbal plant (SNME) with INH/RFP reduced elevated serum alanine aminotransferase (ALT), aspartate aminotransferase (AST), alkaline phosphatase (ALP) and (bilirubin total \&direct) levels but also decreased the elevated malondialdehyde (MDA) \& tumor necrosis factor- $\alpha$ (TNF- $\alpha$ ) contents in liver homogenate. Moreover, co-administration of herbal plant (SNME) with INH/RFP increased glutathione peroxidase (GPX) \& adiponectin activity. Solanum nigrum administration to rats, in present study, led to a remarkable alteration of histological changes observed in INH/RFP group. It is concluded that Solanum nigrum might be considered as adjuvant drug in treatment of liver disorder and/or as hepatoprotective therapy with anti-tubercular drugs.
\end{abstract}

Keywords: Adiponectin, Hepatotoxicity, Isoniazid, Rats, Rifampicin, Solanum nigrum.

Original Article:

https://dx.doi.org/10.21608/j

avs.2019.63436

Received 23 August, 2019. Accepted 25 September,2019. Published in October 2019.

This is an open access article under the term of the Creative Commons Attribution 4.0 (CC-BY) International License . To view a copy of this license, visit http://creativecommons.org/lic enses/by/4.0/

J. Appl. Vet. Sci., 4(2): 52-61.

\section{INTRODUCTION}

The incidence of hepatotoxicity is much higher in Egypt and other developing countries owing to several factors such as acute or chronic liver disease, high incidence of viral hepatitis, malnutrition as well as indiscriminate use of tuberculosis (TB) drugs, this hepatotoxicity may be resemble viral hepatitis (Makhlouf et al., 2008; Yu et al., 2010).

Drug Induced Liver Injury (DILI) is caused by a wide array of medications especially antibiotics (Chalasani et al., 2008). As TB causing maximum number of deaths in the world (Daniel, 2006). So the need of uses its treatment is much higher but hepatotoxicity induced by antitubercular drug also remains the big problem for health professionals through increasing lipid peroxidation, altering the profile of antioxidant enzymes leading to an oxidative stress, cell damage and necrosis (Georgieva et al., 2004; Tayal et al., 2007; Santhosh et al., 2007).

Although rifampicin (RFP) and Isoniazid (INH) are first-line drugs for anti-TB therapy, the uses of these drugs caused severe liver dysfunction, the later remains a significant problem for their uses in clinical treatment (Nanashima et al., 2012). Where combination therapy aggravates their adverse effects than single remedy (Kishore et al., 2007).

Hepatotoxicity is a state of inflammation characterized by elevated levels of TNF- $\alpha$ which lead to a reduction of adiponectin expression in adipose tissue through a paracrine or endocrine mechanism (Lin et al., 1998). Adiponectin, a protein secreted by 
adipocytes, has shown to have a preventive effect on endotoxin-induced lethal liver injury insulin resistance, diabetes and cardiovascular diseases (Masaki et al., 2004; Geagea et al., 2018).

Adiponectin exerts its effects through interaction with two receptors: AdipoR1 and AdipoR2, AdipoR2 is highly expressed in the liver (AntunaPuente et al., 2008), it exerts its action in the liver by its ability to regulate steatosis, insulin resistance, inflammation and fibrosis (Moschen et al., 2012; Frühbeck et al., 2017).

Nature is a complete and big source of remedies to cure all of human kind insults (Kokate $\boldsymbol{e t}$ al., 2002), In addition, modern medicine is so hopeless due to presence of very few choices in term of treatment for liver diseases because some of treating drugs are themselves hepatotoxic for example, interferons which elevate transaminases (Hayden, 2006). It has shown that natural antioxidant effect is the central role in hepatoprotective effects where many reports proved a presence of relationship between antioxidant effects of many bioactive compounds/plant extracts and hepatoprotection against hepatotoxininduced liver damage and also in the reduction of total mortality (Pérez-Jiménez and Saura-Calixto, 2008; Choi et al., 2009 and Yousef et al., 2010).

Solanum nigrum (SN), known as Makoi or black nightshade, is the most important member of solanaceae family. It found in moist habitats in different kinds of soils as a weed (fig. 1) (Fallah et al., (2005). It can be cultivated in tropical and subtropical climates (Mbagwu et al., 2007; Shivakumar and Vidyasagar 2013).

Fig.1. Solanum nigrum Leaves, flowers and fruit of S. nigrum (Solanum nigrum - Wikipedia, the free encyclopedia-en.wikipedia.org ).

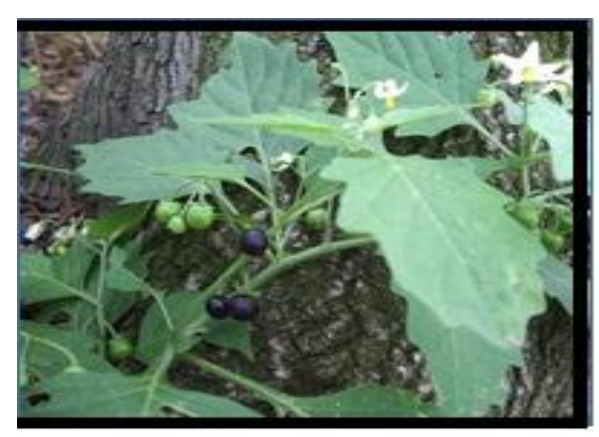

Solanum nigrum extract (SNE) has multiple bio- active materials in form of phenolics, alkaloids (solanine) and flavonoids that were revealed to be a potential antioxidant by scavenging of hydroxyl radicals and 2, 2-Diphenyl-1-picrylhydrazyl radical (DPPH) radicals and has chemo-preventive properties
(Son et al., 2003). It possess a wide spectrum of medicinal properties against gastrointestinal disorders such as anti-ulcerogenic properties (Jainu and Devi 2006), anti-fibrotic activity (Hsieh et al., 2008), potent antifungal (Sridhar et al., 2011), cytoprotective, antimicrobial (Zubair et al., 2011), antinociceptive and antipyretic properties (Zakaria et al., 2006). It also has activities against pain, fever and liver disorders (Kumar, 2012); moreover, it has antioxidant (Liu et al., 2013) and anticancer activity (Ding $\boldsymbol{e t}$ al., 2013) and exhibit protective effect against hepatitis B virus infection (De Silva et al., 2003).

The aim of this study is to investigate the hepatoprotective, antioxidant, anti-inflammatory effects of one of natural products' extract Solanum nigrum methanolic extract on atituberculous drugsinduced hepatotoxicity to help these tuberculous patient the continuation of the treatment courses with minimal drawbacks.

\section{MATERIALS AND METHODS}

Plant

SN whole plants were collected fromrural area of villages (Dakahlia governeorate), the plants and its dry fruit were identified and authenticated as plants of SN by the taxonomy section of the Department of Biological Sciences, Cairo University, Egypt.

\section{Preparation of Alcoholic Extract}

This extract were obtained by the following steps: Grinding SN fruits in blender till obtain powder, maceration with petroleum ether to remove fatty substances and the marc was further exhaustively extracted with $70 \%$ ethanol for 3 days ( $3 \times 5 \mathrm{~L})$, Soaking this powder in methyl alcohol for seven days with rotation every day, Filtration by using piece of cotton, separation by filtration and concentration on rotavapour (Buchi, USA) and then dring in lyophilizer (Labconco, USA) under reduced pressure, repeat extraction was carried out, the extract will be stored in an airtight container in a refrigerator below $10{ }^{\circ} \mathrm{C}$.

\section{Drug}

INH/RFP was purchased from Sandoz GmbH, Biochemiestrasse, Austria. Silymarin was purchased from Novartis Pharma, Cairo; Egypt.

\section{Animals}

Forty eight adult male Wistar albino rats, weighing between 200-250 g were obtained from the animal house colony, National Research Centre, Giza, Egypt. All animals were kept in metal cages at animal house of National Research Centre, Giza under standard conditions. Food and water was available to the rats. All experiments were carried out according to the ethical guidelines for care and use of experimental 
animals approved by the Ethical Committee of the National Research Centre. (Ethical approval: 13-157) EXPERIMENTAL DESIGN

Animals were randomly divided into six groups, each of eight animals. Group I: (Negative control): rats daily received only $1 \mathrm{ml}$ saline for 28 days, orally). Group II: (Intoxicated group): rats daily received 50 $\mathrm{mg} / \mathrm{kg}$ each of INH-RIF, orally for twenty- eight days to induce hepatic injury (Mujahid et al., 2017). Group III. (Silymarin group): daily received silymarin orally at a dose of $50 \mathrm{mg} / \mathrm{Kg}$ ref for 28 days concurrent with INH and RFP; for 28 days (Wang et al., 2018). Group IV-VI: Animals in this group were given three different oral doses 250, 500 and $1000 \mathrm{mg}$ of Solanum nigrum methanolic extract $/ \mathrm{kg}$ of the rat body weight concurrent with INH and RFP; for 28 days respectively (Lin, 2008).

\section{Blood collection and tissue preparation}

Blood samples were collected from the retroorbital venous plexus of rats under light ether anesthesia and collected in clean test tubes, allowed to clot, then centrifuged for 10 minutes at 3000 r.p.m. Serum was separated and stored into eppendorff tubes at $-20{ }^{\circ} \mathrm{C}$ to be used for determination of liver function parameters. After collection of blood samples, rats were sacrificed by cervical dislocation and their livers were immediately removed. Moreover, livers of rats were divided into 2 parts; the first liver samples were kept at $\left(-80{ }^{\circ} \mathrm{C}\right)$ for determination of hepatic levels of Malondialdehyde (MDA), glutathione peroxidase (GPx), tumor necrosis factor-alpha (TNF- $\alpha$ ) and adiponectin. The second liver samples were preserved in phosphate buffered formalin $10 \%$ for further histopathological investigation.

\section{Biochemical analysis of serum samples.}

Aspartate aminotransferase and alanine aminotransferase (ALT, AST) were determined using Reitman and Frankel, (1957) methods. Alkaline Phosphate (ALP) was determined as outlined by Belfield and Goldberg, (1971), total and direct bilirubin were determined according to Walters and Gerade, (1970) using Biodiagnostic kits, Egypt. Hepatic Malondialdehyde (MDA) and glutathione peroxidase (GPx) was estimated colorimetrically (Ohkawa et al., 1979; Paglia and Valentine 1967) using Biodiagnostic kits. Both tumor necrosis factoralpha (TNF- $\alpha$ ) and adiponectin were quantified by (Pennica et al., 1984; Kojima et al., 2003) using ELISA kits.

\section{Liver histopathological assessment}

For histopathological studies, few-millimeters mid-sections of the left lobes, of the livers excised from each group were processed for light microscopy. The processing involved fixing the tissue specimens in a $10 \%$ neutral buffered formalin solution, preparing the blocks in paraffin, cutting sections 5-6 $\mu \mathrm{m}$ in thickness, and staining the sections with haematoxylin-eosin stain. (Carleton et al., 1980).

\section{Statistical analysis}

In the present study, all results were expressed as mean \pm standard error of the mean. Data analysis was achieved by one-way analysis of variance (ANOVA) followed by Tukey comparison test using software program ASSISTAT (Version 7.7 beta). Difference was considered significant when $\mathrm{P}<0.05$.

\section{RESULTS}

Fig.6 (A-F): Histopathology of rat liver showing (A) normal morphology with preserved hepatic architecture of the control group; (B) diffuse hepatocellular steatosis, multifocal sinusoidal dilatation with congestion and leucocytosis, large focal area of hepatocellular necrosis infiltrated with mononuclear inflammatory cells, focal area of hepatocellular necrosis infiltrated with mononuclear inflammatory cells associated with abundant apoptosis, intense infiltration of Portal triads with mononuclear inflammatory cells associated with individual necrosis of periportal hepatocytes Large focal area of hepatocellular necrosis infiltrated with mononuclear inflammatory cells of RFP/INH $50 \mathrm{mg} / \mathrm{kg}$; (C) Vacuolar degeneration of hepatocytes associated with sporadic cell necrosis of Silymarin group; (D) steatosis of the surrounding periportal hepatocytes in group treated with Solanum nigrum $250 \mathrm{mg} / \mathrm{kg}$; (E) mild focal sinusoidal leucocytosis associated with singe cell necrosis and activation of kupffer cells of Solanum nigrum $500 \mathrm{mg} / \mathrm{kg}$ group; (F) apparently normal hepatocytes with increased number of binucleated cells of Solanum nigrum $1000 \mathrm{mg} / \mathrm{kg}$ group. 
Abdel-Hameed M.Fayed et al...

Table 1: Effects of silymarin and Solanum nigrum on serum liver enzymes.

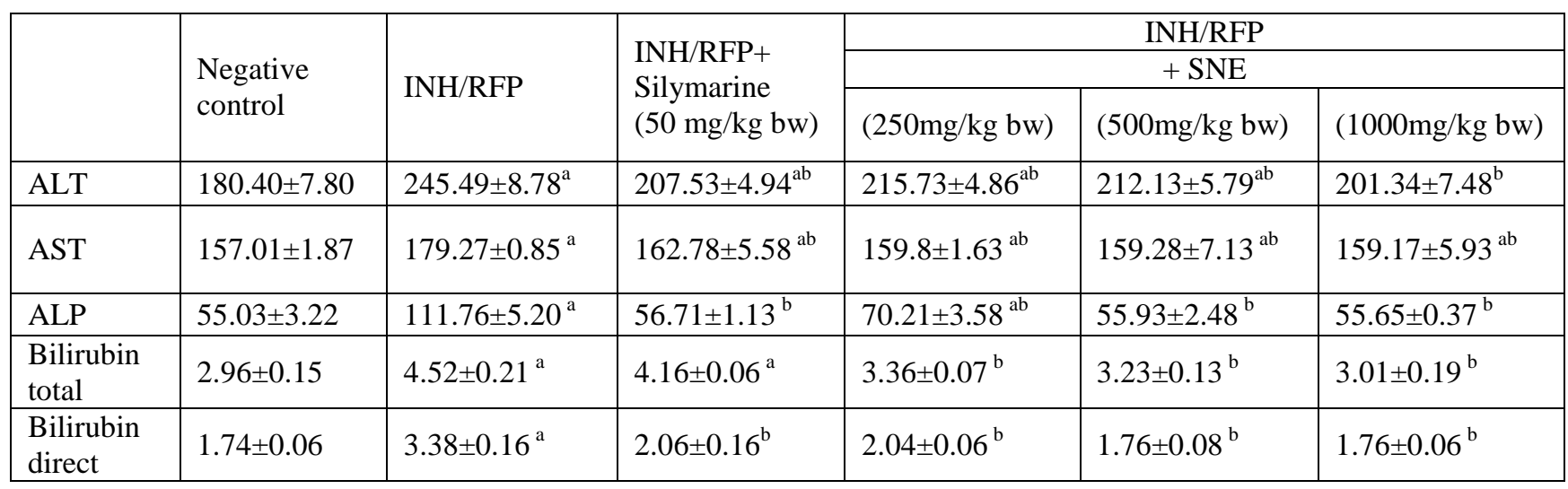

Data were expressed as mean \pm SE $(n=6)$.

Statistical analysis was carried out by one-way ANOVA followed by LSD test.

$\mathrm{a}=$ Significantly different from normal control at $\mathrm{P}<0.05$

$\mathrm{b}=$ Significantly different from RIF/INHat $\mathrm{P}<0.05$

Fig. 2, 3. Effects of Solanum nigrum and silymarin on liver content of antioxidant status:
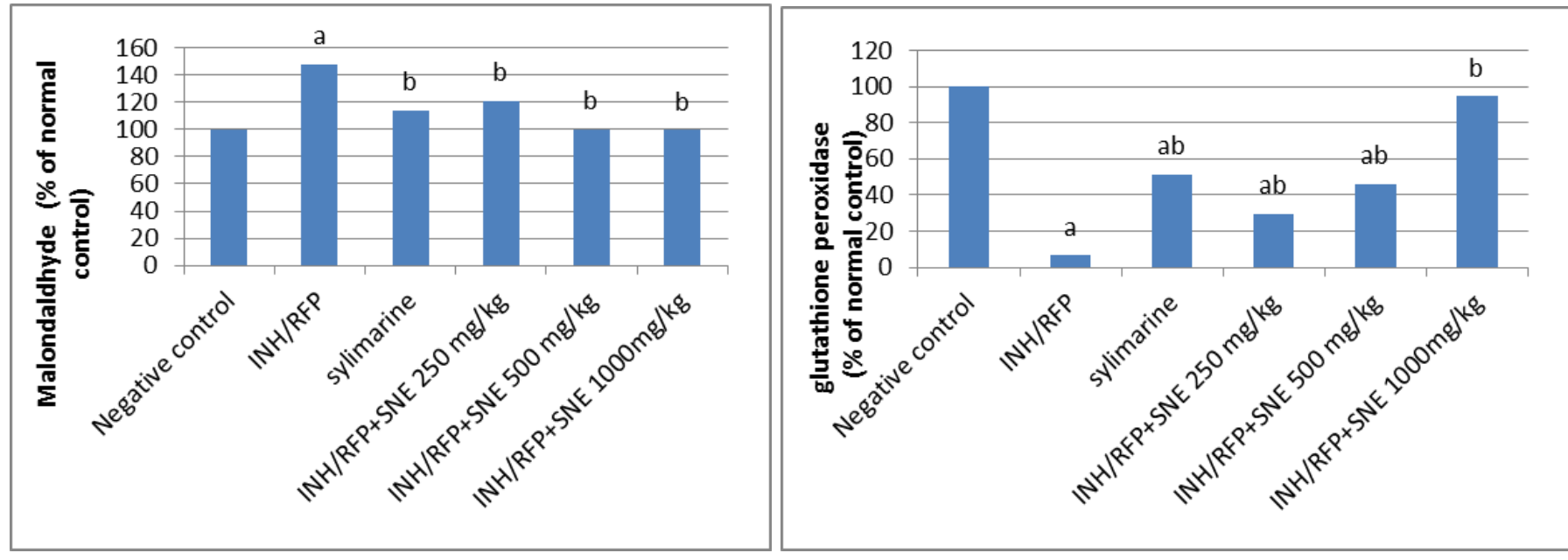

Fig. 4. Effects of Solanum nigrum and silymarin on liver content of $\alpha$ TNF- $\alpha$ content

Fig.5. Effects of Solanum nigrum and silymarin on liver content of adiponectin
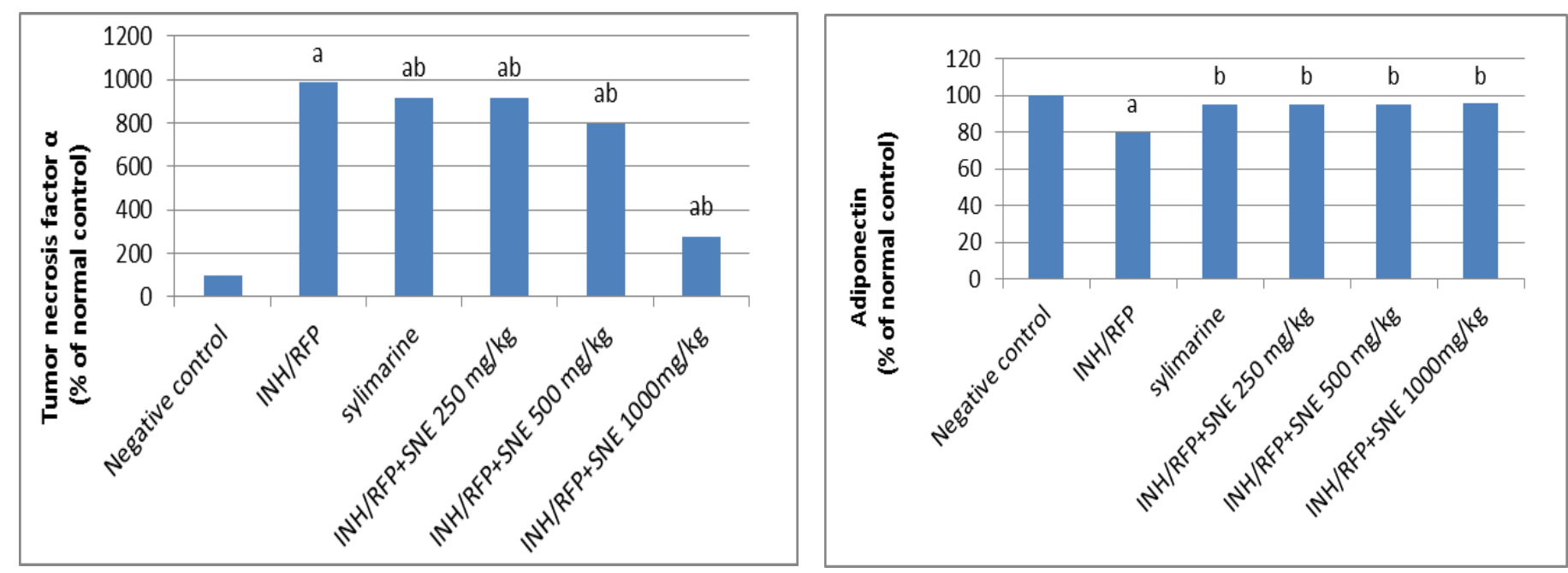
Figure 6: Effects of Solanum nigrum and silymarin on histopathology
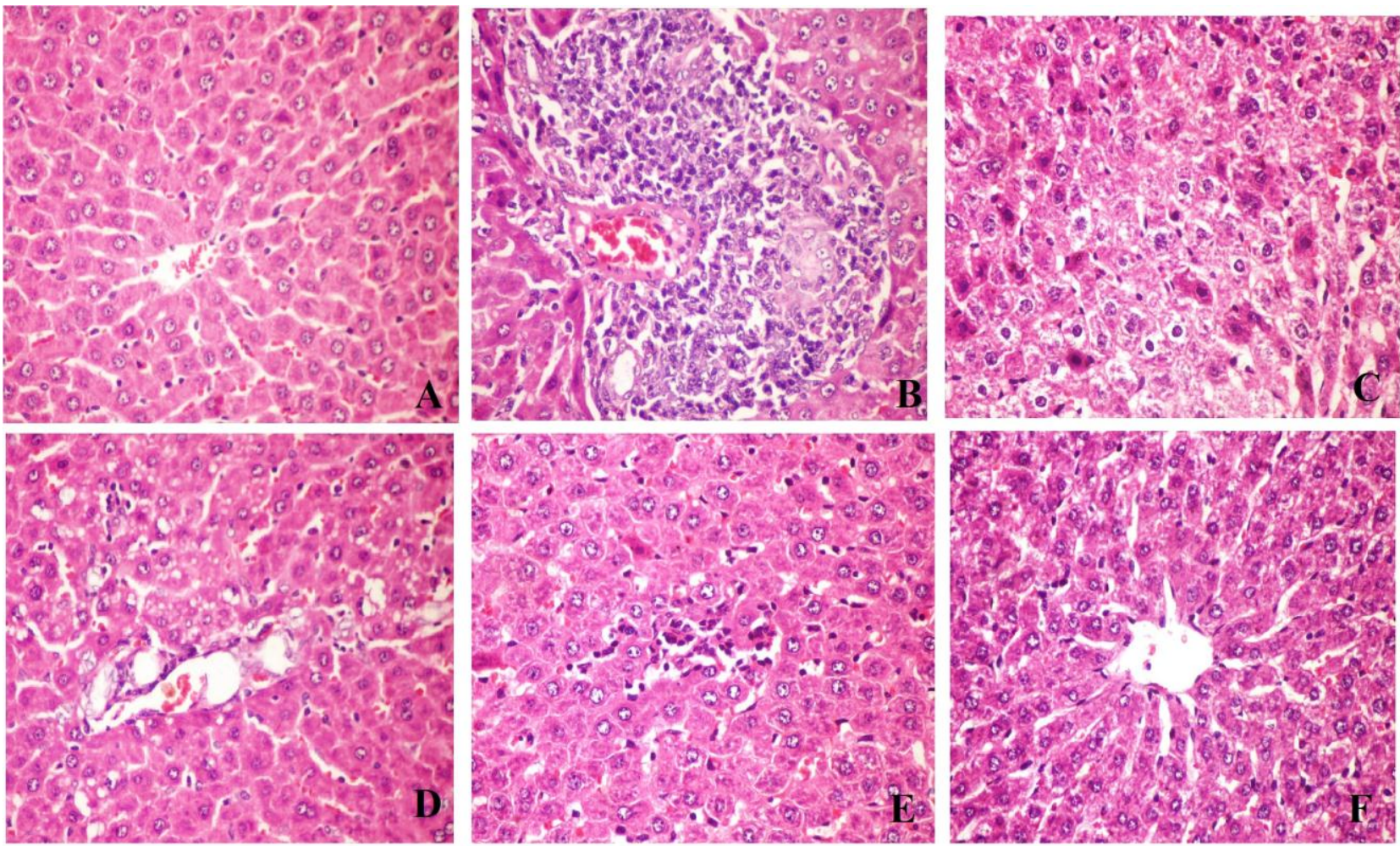

\section{DISCUSSION}

Liver disorders are a major global concern owing to its prognosis which extremely poor and high mortality in addition to the lack of effective preventive/ treatment options So it requires us to search new effective medicines without side effects to participate in solving this public health problem that represent as obstacle to the advances in the field of modern medicine (Choi et al., 2011).

The selection of rats as a model of INHinduced hepatotoxicity not only for its similarity in genetically determined acetyltransferase activity with humans but also for a higher amidase activity which is responsible for releasing large amount of acetylhydrazine and make it more sensitive for induction of hepatotoxicity(Georgieva et al., 2004). Although the regimen of RIF/INH is more effective in tuberculosis (TB) but Rifampicin addition to regimen induces isoniazid hydrolase, increasing hydrazine production resulting in increased risk of hepatotoxicity (Steele et al., 1991; Tayal et al., 2007).

In the present study, administration of RIP/INH at a dose of $50 \mathrm{mg} / \mathrm{kg}$ b.wt of each induce hepatotoxicity in rat, indicated by marked increase in the levels of liver enzymes (AST, ALT, ALP, total and direct bilirubin) compared to the normal control rat group, refers to induction of hepatotoxicity as confirmed by salama et al., (2018); Qader et al.
(2014). Elevated levels of transaminases (AST, ALT) are the specific mirrors of hepatocelluar damage and necrosis especially in treatment with antituberculosis drugs as early recognized as good prognosis, especially ALT is a more specific and sensitive indicator of hepatocellular damage (Giboney, 2005; Khalili et al., 2009; Ozer et al., 2008).

Serum ALP level elevation may be due to increased production of ALP by hepatic parenchymal or duct cells (Swaroop and Shivalinge, 2012). While hyperbilirubinemia may be due to inability of hepatocytes to excrete bilirubin in the normal way, so bilirubin considered as more specific indicator for hepatic clearance, capacity of liver to metabolize drugs or xenobiotics and severity of liver damage (Alshawsh et al., 2011; Dufour et al., 2000).

Treatment of intoxicated group with Solanum nigrum extract significantly mitigates the increased activities of liver marker enzymes and serum bilirubin (total and direct) to near normal levels, this may be an outcome of stabilization of hepatocyte cell membrane and restoring the functional status of the liver from INH toxicity. Reports came in the same boat showing that Solanum nigrum extract has the ability to preserve the structural integrity of plasma membrane or contributed in there generation of injured liver cells (Bhavani et al., 2015; Lin et al., 2008, Hsieh et al.,2008; Raju et al., 2003). 
Also there is a good indicator for improving of liver state was noted by the action of silymarin in form of reduction of level of liver enzymes (ALT, AST, ALP) and bilirubin (total and direct) (Wang et al., 2018; Hassan and EL-Gendy, 2003; Ilyas et al., 2011). Our findings when compared with the standard drug silymarin, which is discovered for over than fifty years, widely used in hepatoprotection and medically scheduled for liver diseases and hepatitis since year 2000 (Encyclopedia 2019). Thus, from the above findings it is obvious that Solanum nigrum fruit extract has a prominent hepatoprotective effect against liver damage.

Hepatocyte cell membrane integrity is the main protector for cytosol, by action of oxidative stress resulted from antituberculosis drugs it generates lipid peroxides causing loss of the integrity and hepatocellular necrosis. (Jadhav et al., 2010). Current experiment exhibited marked oxidative stress signified by increased malondaldhyde (MDA) levels leading to a marked decline in the levels of glutathione peroxidase (GPx) due to effect of RIF/INH administration compared to the normal rats. Our study conflicts with the other results proved by Shih et al., (2013); Jeyakumar et al., (2008); Prabakan et al., (2000) and Pal et al., (2006).

The combination therapy of INH with RFP increases lipid peroxidation through formation of highly reactive oxygen species (ROS), Qader et al., 2014, Second, reduction in glutathione level resulting in tissue injury (Shanker $\boldsymbol{e t}$ al., 2005), altering the profile of antioxidant enzymes which in turn leading to an oxidative stress and cell damage (Georgieva $\boldsymbol{e t}$ al., 2004; Santhosh et al., 2007). The administration of silymarin to rats achieved the normal levels of MDA as well as increasing the activities of GPx, protecting rats that received RIF/INH against lipid peroxidation, these result refines with the other result of Zhang et al., (2013). SNL fruit extract contain higher values of glycoprotein, these glycoproteins showed a dosedependent radical scavenging activity on free radicals, including 1, 1-diphenyl-2- picrylhydrazyl (DPPH) radicals, hydroxyl radical $(\mathrm{OH})$, and superoxide anion (O2 -) (Heo and Lim, 2004).

The current study revealed that administration of Solanum nigrum resulted in mitigating RIF/INH oxidative effects and achieving cellular protection against oxidative stress, this manifested by a decrease in the levels of MDA and increased the activity of GPx as compared to hepatotoxic rats. the lipid peroxidation is a state of destructive process of liver cells causing elevations in MDA level and failure of antioxidant defense mechanisms these actions were remolded by action of Solanum nigrum fruit extact supplementation (Gupta et al., 2009) so this beneficial antioxidative activity of the extract might be considered as an adjuvant drug in liver disorders treatment (Lee $\boldsymbol{e t}$ al., 2005; Sankaran, 2012).

It is proved that, the antioxidant property of SN is due to its active ingredient, higher contents of polyphenolic compounds, vitamin $\mathrm{C}$ and $\beta$-carotene. Plus, saponins (nigrumin I \& II), responsible for hepatoprotective activity (Arulmozhi et al., 2012). Several studies proved that tumor necrosis factor alpha has important role in the inflammatory process as it is one of proinflammatory cytokines that Activate NF-kB which has the master role of NF-KB in activation of liver fibrosis (Ribeiro et al., 2004; Lv et al., 2007), that becomes the driving force of inflammation via the activation of the major fibrogenic molecule transforming growth factor $\beta$ (TGF- $\beta$ ), and stimulates the survival and production of activated myofibroblasts through differentiation of hepatic stellate cells (HSCs) (Elsharkawy and Mann, 2007).

In the present study, RIF/INH administration to rats elevated the levels of TNF- $\alpha$ content compared to the normal rats, which indicating that RIF/INH could induce a liver inflamation in the rats. The elevation of this parameter was reported in at a dose of $50 \mathrm{mg} / \mathrm{kg}$ b.wt of each. Our study agrees with Hussein $\boldsymbol{e t}$ al., (2016). Solanum nigrum administration to rats, in present study decreased the levels of TNF- $\alpha$ liver content compared to hepatotoxic rats, this reduction possibly may be due to its content of (E)-ethyl caffeate, which possesses maximum inhibition for leukotrienes (Jian et al., 2007). Anti-leukotrienes are currently prescribed to treat various inflammatory diseases such as asthma and atopic rhinitis, and thus could be considered as a potential anti-inflammatory therapeutic compound (Jain et al., 2011).

The above mentioned action also occurred with silymarin administration to rats by the reduction of TNF- $\alpha$ liver content as compared to the hepatotoxic rats, these results agree with reports of (Cho $\boldsymbol{e t}$ al., 2000 and Dehmlow et al., 1996). Adiponectin a mammalian circulating protein produced in adipose tissue is an insulin-sensitizing hormone suppresses, has a beneficial role in suppressing the inflammation especially liver fibrosis via regulation of immunocytokines, including TNF- $\alpha$ and also improves nonalcoholic steato-hepatitis via the inhibition of lipogenic factors and TNF- $\alpha$ (Xu et al., 2003); Anil Kumar et al., 2015).It also suppress TNF- $\alpha$-induced adhesion molecule expression in vascular endothelial cells (Yokota et al., 2000).

Adiponectin exerts its functions by binding to the plasma membrane receptors called AdipoRs, there are two types: AdipoR1 control important pathway in skeletal muscles and AdipoR2 that activates peroxisome proliferator-activated receptors (PPAR $\alpha)$ pathway in the liver to decrease inflammation (Yamauchi et al., 2007). 
In the present study RIF/INH administration to rats decreased the levels of adiponectin liver content compared to the normal rats, which indicating that RIF/INH could induce a liver damage in the rats. Our result confirmed what explained by Tang et al., 2002 ; Anil Kumar et al., 2015. That is presence of inversely relationship between TNF- $\alpha$ and adiponectin so the acceleration in liver fibrosis especially in obese patient is due to deficiency of adiponectin but if there are elevated or adequate level of adiponectin as be explained in Solanum nigrum or silymarin groups indicates hepatoprotective and anti-inflammatory effects.

Histopathological examination confirmed our laboratory findings where RIF/INH administration to rats showing diffuse hepatocellular steatosis, multifocal sinusoidal dilatation with congestion and leukocytosis, large focal area of hepatocellular necrosis infiltrated with mononuclear inflammatory cells peri-portal hepatocytes associated with abundant apoptosis and intense infiltration of portal triads, our finding is in the same line with (Bais and Saiju, 2014; Lian et al., 2013). While histopathological figure of silymarin group revealed minimal reduction in the severity of the liver damage represented by vacuolar degeneration of hepatocytes associated with sporadic cell necrosis. Our result supported by salama et al., (2018).

The treatment with Solanum nigrum especially high dose revealed remarkable preservation in their histological profiles as compared with hepatotoxic group showing apparently normal hepatocytes with increased number of binucleated cells, this agrees with Subash et al., (2011).

\section{CONCLUSION}

The findings of our study suggest that Solanum nigrum fruit extract has antioxidant effect that detoxifies the toxic effects of isoniazid and prevent its aggrevation by rifampicin and that it is alsoinvolved in regeneration processes, preventing from organ damage and necrosis. Therefore, dietary supplementation of Solanum nigrum fruits offers protection against liver toxicity and presents a new promising adjuvant drugs with patients treated with antitubercular drugs.

\section{Declaration of Competing interest}

On behalf of all authors, I hereby declare that no conflict of interest may interfere with the publication of the manuscript.

\section{REFERENCES}

ALSHAWSH, M.A., ABDULLA, M.A., ISMAIL, S. AND AMIN, Z.A. 2011. Hepatoprotective Effects of Orthosiphon stamineus Extract on ThioacetamideInduced Liver Cirrhosis in Rats. Evidence-based complementary and alternative medicine 2011: 103039.
ANIL KUMAR, S., HIMA KUMARI, P., SHRAVAN KUMAR, G., MOHANALATHA, C., KAVI KISHOR, P. B. 2015. Osmotin: a plant sentinel and a possible agonist of mammalian adiponectin. Frontiers in plant science 6:163. doi:10.3389/fpls.2015.00163.

ANTUNA-PUENTE B., FEVE B., FELLAHI S., BASTARD J.P. 2008. Adipokines: The missing link between insulin resistance and obesity. Diabetes Metab 34(1): 2-11.

ARULMOZHI, V., KRISHNAVENI, M., MIRUNALINI, S. 2012. Protective effect of Solanum nigrum fruit extract on the functional status of liver and kidney against ethanol induced toxicity. J Biochem Tech 3(4):339-343.

BAIS, B., AND SAIJU, P. 2014,. Ameliorative effect of Leucas cephalotes extract on isoniazid an rifampicin-induced hepatotoxicity. Asian Pacific Journal of Tropical Biomedicine 4(2):S633-S638.

BELFIELD, A. AND GOLDBERG, D. 1971. Colorimetric determination of alkaline phosphatase activity. Enzyme 12(5): 561-568.

BHAVANI, R., GEETHA, G., SANTHOSHKUMAR, J., RAJESHKUMAR, S. 2015. Evaluation of Antibacterial action and Hepatoprotective efficiency of Solanum nigrum leaves extract on acetaminophen induced hepatotoxicity. Research $J$. Pharm. and Tech. 8(7): 893-900.

CARLETON, H.M., DRURY, R.A.B., WALLINGTON, E.A. 1980. Carleton's histological technique. Journal of clinical pathology 4th edn. Pp. 116.

CHALASANI, N., FONTANA, R.J., BONKOVSKY, H.L., WATKINS, P.B., DAVERN, T. SERRANO, J., YANG, H., ROCHON, J. 2008. Drug Induced Liver Injury Network (DILIN), Causes, clinical features, and outcomes from a prospective study of drug-induced liver injury in the United States. Gastroenterology 135:1924-1934.

CHO, J.Y., KIM, P.S., PARK, J., YOO, E.S., BAIK, K.U., KIM, Y.K. AND PARK, M.H. 2000. Inhibitor of tumor necrosis factor-alpha production in lipopolysaccharide-stimulated RAW264.7 cells from Amorpha fruticosa. J Ethnopharmacol., 70:127-133.

CHOI, J.H., CHOI, C.Y., LEE, K.J., HWANG, Y.P., CHUNG, Y.C., JEONG, H.G. 2009. Hepatoprotective effects of an anthocyanin fraction from purple-fleshed sweet potato against acetaminopheninduced liver damage in mice. $J$. Med. Food 12: 320-326.

Choi, J.H., Kim, D.W., Yun, N., Choi, J.S., Islam, M.N., KIM, Y.S., LEE, S.M. 2011. Protective effects of hyperoside against carbon tetrachloride-induced liver damage in mice. J. Nat. Prod. 74: 1055-1060.

DANIEL, T.M. 2006. Wilhelm Conrad Rötgen and the advent of thoracic radiology. Int. J. Tuberc. Lung. Dis., 10(11):1212-4.

DE SILVA, H.A., SAPARAMADU, P.A., THABREW, M.I., PATHMESWARAN, A., FONSEKA, M.M., DE SILVA, H.J. 2003. Liv-52 in alcoholic liver disease: a prospective, controlled trial. $J$. Ethnopharmacol., 84: 47-50. 
DEHMLOW, C., ERHARD, J., DE GROOT, H. 1996. Inhibition of Kupffer cell functions as an explanation for the hepatoprotective properties of silibinin. Hepatology. 23:749-754.

DING, X., ZHU, F., YANG, Y., LI, M. 2013. Purification, antitumor activity in vitro of steroidal glycoalkaloids from black nightshade (Solanum nigrum L.) Food Chemistry. 141(2): 1181-1186.

DUFOUR, D.R., LOTT, J.A., NOLTE, F.S., GRETCH, D.R., KOFF, R.S., ET AL. 2000. Diagnosis and monitoring of hepatic injury: II. Recommendations for use of laboratory tests in screening, diagnosis and monitoring. Clin Chem 46: 2050-2068.

ELSHARKAWY, A.M. AND MANN, D.A. 2007. Nuclear factor-kappaB and the hepatic inflammationfibrosis-cancer axis. Hepatology 46(2): 590-597.

Encyclopedia.com. 17 Sep. 2019. "milk thistle." A Dictionary of Food and Nutrition. https://www.encyclopedia.com.

FALLAH HUSEIN, H.S.M, ALAVIAN HESHMAT, R., HEYDARI, M.R., ABOLMAALI, K. 2005. The efficacy of Liv-52 on liver cirrhotic patients: A randomized, double-blind, placebo-controlled first approach Phytomedicine 12(9): 619-624.

FRÜHBECK, G., CATALÁN, V., RODRÍGUEZ, A., RAMÍREZ, B., BECERRIL, S., SALVADOR, J.,PORTINCASA, P., COLINA, I., GÓMEZAMBROSI, J. 2017. Involvement of the leptinadiponectin axis in inflammation and oxidative stress in the metabolic syndrome. Scientific Reports.7, pp. 6619.

GEAGEA, A.G., MALLAT, S., MATAR, C.F., ZERBE, R., FILFILI, E., FRANCIS, M., HAIDAR, H., JURJUS, A. 2018. Adiponectin and Inflammation in Health and Disease: An Update. 5:20-32.

GEORGIEVA, N., GADJEVA, V., TOLEKOVA, A. 2004. New isonicotinoylhydrazones with SSA protect against oxidative-hepatic injury of isoniazid. TJS 2:37-43

GIBONEY, P.T. 2005. "Mildly Elevated Liver Transaminase Levels in the Asymptomatic Patient". Am Fam Physician.71 (6): 1105 10. PMID 15791889.

GUPTA, A. K., GANGULY, P., MAJUMDER, U. K., GHOSAL, S. 2009. hepatoprotective and antioxidant effects of total extracts and stereoidal saponins of Solanum xanthocarpum and Solanum nigrum in paracetamol induced hepatotoxicity In rats. Pharmacologyonline 1: 757-768.

HASSAN, H.A. AND EL-GENDY, A.M. 2003. Evaluation of silymarin and / or ginger effect on induced hepatotoxicity by carbon tetrachloride in male albino rats. The Egyptian Journal of Hospital Medicine 12: 101 - 112. I.S.S.N: 12084 1687-2002.

HAYDEN, F.G. 2006. Antiviral Agents ( Nonretroviral ): In: Goodman and Gilmans The Pharmacological Basics of Therapeutics, Goodmans L S, Gilman A, Brunton L L, Lazo J S And Parker K L. (Eds.) $11^{\text {th }}$ Edn., McGraw-Hill Publication Co. Inc., New York, USA., ISBN-13: 9780071422802 , pp: 1243-1271.

HEO, K.S., AND LIM, K.T., 2004. Antioxidative effects of glycoprotein isolated from Solanum nigrum L. J Med Food 7(3):349-57.
HSIEH, C.C., FANG, H.L., LINA, W.C. 2008. Inhibitory effect of Solanum nigrum on thioacetamideinduced liver fibrosis in mice. J. Ethnopharmacol. 119: 117-121.

HUSSEIN, O.E., GERMOUSH, M.O., MAHMOUD, A.M. 2016. Ruta graveolens Protects Against Isoniazid/Rifampicin-Induced Nephrotoxicity through Modulation of Oxidative Stress and Inflammation. Glob J Biotechnol Biomater Sci 1(1): 017-022.

ILYAS, N., SADIQ, M., JEHANGIR, A. 2011. Hepatoprotective effect of garlic (allium sativum) and milk thistle (silymarin) in isoniazid induced hepatotoxicity in rats. Biomedica. 27: $166-170$.

JADHAV, V.B., THAKARE, V.N., SURALKAR, A.A., DESHPANDE, A.D., NAIK, S.R. 2010. Hepatoprotective activity of Luffa acutangula against $\mathrm{CCl} 4$ and rifampicin induced liver toxicity in rats: A biochemical and histopathological evaluation. Indian J Exp Biol.48:822-9. [PubMed] [Google Scholar]

JAIN, R., SHARMA, A., GUPTA, S., SARETHY, I.P., GABRANI, R., 2011. Solanum nigrum: Current Perspectives on Therapeutic Properties Alternative Medicine Review Monograph 16(1):78-85.

JAINU, M. AND DEVI, C.S. 2006. Antiulcerogenic and ulcer healing effects of Solanum nigrum (L.) on experimental ulcer models: possible mechanism for the inhibition of acid formation. J Ethnopharmacol. 104(1-2):156-63.

JEYAKUMAR, R., RAJESH, R., MEENA, B., RAJAPRABHU, D., GANESAN, B., BUDDHAN, S., ANANDAN, R. 2008. Antihepatotoxic effect of Picrorhiza kurroa on mitochondrial defense system in antitubercular drugs (isoniazid and rifampicin)induced hepatitis in rats. Journal of Medicinal Plants Research 2(1): 017-019.

JIAN, L., QINGWANG, L., TAO, F., TAO, Z., KUN, L., RUI, Z., ZENGSHENG, H., DAWEI, G. 2007. Antitumor activity of crude polysaccharides isolated from Solanum nigrum Linne on U14 cervical carcinoma bearing mice. Phytother. Res. 21(9): 832-840. KHALILI, H., DASHTI-KHAVIDAKI,
RASOOLINEJAD, ETMINANA, M. 2009. Anti-tuberculosis drugs related hepatotoxicity: Incidence, risk factors, pattern of changes in liver enzymes and outcome. DARU 17: 163-167.

KISHORE, P.V., PALAIAN, S., PAUDEL, R., MISHRA, P., PRABHU, M., SHANKAR, P.R. 2007. Drug induced hepatitis with anti-tubercular chemotherapy: Challenges and difficulties in treatment. Kathmandu University Medical Journal 5, 2 (18):256-260.

KOJIMA, S., FUNAHASHI, T., SAKAMOTO, T., MIYAMOTO, S., SOEJIMA, H., HOKAMAKI, J., $\boldsymbol{E T} \boldsymbol{A L}, \mathbf{2 0 0 3}$. The variation of plasma concentrations of a novel, adipocyte derived protein, adiponectin, in patients with acute myocardial infarction. Heart 89(6): 667. 
KOKATE, C.K., PUROHIT, A.P., GOKHALE, S.B. 2002. Textbook of pharmacognosy, Nirali prakasan: Pune. 18:1-4 pp.

KUMAR, A., 2012. A review On Hepatoprotective Herbal Drugs. Int. J. Res.Pharm.chem., 2(1) 92-102.

LEE, S-J., KO, J-H., LIM, K. AND LIM, K-T. 2005. $150 \mathrm{kDa}$ glycoprotein isolated from Solanum nigrum Linne enhances activities of detoxicant enzymes and lowers plasmic cholesterol in mouse. Pharmacological Research 51(5): 399-408.

LIAN, Y., ZHAO, J., XU, P., WANG, Y., ZHAO, J. ET AL. 2013. Protective Effects of Metallothionein on Isoniazid and Rifampicin-Induced Hepatotoxicity in Mice. PLoS ONE 8(8): $e 72058$. doi:10.1371/journal.pone.0072058.

LIN, H.M., TSENG, H.C., WANG, C.J., LIN, J.J., LO, C.W., CHOU, F.P. 2008. Hepatoprotective effects of Solanum nigrum Linn extract against $\mathrm{CCl}_{4}$ induced oxidative damage in rats. Chem. Biol. Interact. 171(3) 283-293.

LIN, H.Z., YANG, S.Q., ZELDIN, G., DIEHL, A.M. 1998. Chronic ethanol consumption induces the production of tumor necrosis factor-alpha and related cytokines in liver and adipose tissue. Alcohol. Clin. Exp. Res. 22(Suppl.):231S-237S.

LIU, J., ZHANG, H., ZHANG, Y., CHAI, T., 2013. Silicon attenuates cadmium toxicity in Solanum nigrum L. by reducing cadmium uptake and oxidative stress.Plant Physiology and Biochemistry (68)1-7.

LV P., LUO H-S., ZHOU X-P., XIAO, Y-J., PAUL, S.C., SI, X-M., ET AL. 2007. Reversal Effect of Thalidomide on Established Hepatic Cirrhosis in Rats via Inhibition of Nuclear Factor- $\mathrm{B}$ /Inhibitor of Nuclear Factor- $\kappa \mathrm{B}$ Pathway. Archives of medical research 38(1): 15-27.

MAKHLOUF, H.A., HELMY, A., FAWZY, E., ELATTAR, M., RASHED, H.A.G. 2008. A prospective study of antituberculous drug-induced hepatotoxicity in an area endemic for liver diseases. Hepatol Int 2:353-360. DOI 10.1007/s12072-0089085-y

MASAKI, T., CHIBA, S., TATSUKAWA, H., YASUDA, T., NOGUCHI, H., SEIKE, M. YOSHIMATSU, H. 2004. Adiponectin Protects LPS-Induced Liver Injury Through Modulation of TNF- $\alpha$ in KK-Ay Obese Mice. Hepatology 40:177-184.

MBAGWU, F.N., NWACHUKWU, C.U., OKORO, O.O. 2007. Root Anatomical Studies on Solanum Macrocarpum and Solanum nigrum (Solanaceae): Journal of American Science, 3(3): :1-4. (ISSN: 1545-1003). DOI:10.4314/ajb.v8i17.62144

MOSCHEN, A.R., WIESER, V., TILG, H. 2012. Adiponectin: Key Player in the Adipose TissueLiver Crosstalk. Current Medicinal Chemistry 19(32), 5467-5473.

MUJAHID, M., HUSSAIN, T., SIDDIQUI, H.H., HUSSAIN, A. 2017. Evaluation of hepatoprotective potential of Erythrina indica leaves against antitubercular drugs induced hepatotoxicity in experimental rats. Journal of Ayurveda and Integrative Medicine 8:7-12.
NANASHIMA, K., MAWATARI, T., TAHARA, N., HIGUCHI, N., NAKAURA, A. ET $A L, 2012$. Genetic variants in antioxidant pathway: risk factors for hepatotoxicity in tuberculosis patients. Tuberculosis 92: 253-259.

OHKAWA, H., OHISHI, N., YAGI, K., 1979. Assay for lipid peroxides in animal tissues by thiobarbituric acid reaction. Analytical biochemistry 95(2): 351358.

OZER, J., RATNER, M., SHAW, M., BAILEY, W., SCHOMAKER, S., ET AL. 2008. The current state of serum biomarkers of hepatotoxicity. Toxicology 245: 194-205.

PAGLIA, D.E. AND VALENTINE, W.N. 1967. Studies on the quantitative and qualitative characterization of erythrocyte glutathione peroxidase. J. Lab. Clin. Med. 70: $158-169$.

PAL, R., VAIPHEI, K., SIKANDER, A., SINGH, K., RANA, S.V. 2006. Effect of garlic on isoniazid and rifampicin-induced hepatic injury in rats World $J$ Gastroenterol 12(4): 636-639.

PENNICA， D., NEDWIN, G.E., HAYFLICK, J.S., SEEBURG, P.H., DERYNCK, R., PALLADINO, M.A. ET AL. 1984. Human tumour necrosis factor: Precursor structure, expression and homology to lymphotoxin. Nature 312(5996), 724-729.

PÉREZ-JIMÉNEZ，J.，SAURA-CALIXTO，F. 2008 Grape products and cardiovascular disease risk factors. Nutr. Res. Rev. 21: 158-173.

PRABAKAN, M., ANANDAN, R., DEVAKI, T., 2000. Protective effect of Hemidesmusindicus against rifampicin and isoniazid-induced hepatotoxicity in rats. Fitoterapia 71: 55-59.

QADER, G.I., AZIZ, R.S., AHMED, Z.A., ABDULLAH, Z.F., HUSSAIN, S.A. 2014. Protective Effects of Quercetin against Isoniazid and Rifampicin Induced Hepatotoxicity in Rats. American Journal of Pharmacological Sciences 2(3) 56-60.

RAJU, K., ANBUGANAPATHI, G., GOKULAK RISHNAN , V., RAJKAPOOR, B., JAYAKAR, B., MANIAN, S. 2003. Effect of Dried Fruits of Solanum nigrum LINN against CCl4-Induced Hepatic Damage in Rats. Biol. Pharm. Bull. 26(11): 1618-1619.

REITMAN, S. AND FRANKEL, S. 1957. A colorimetric method for the determination of serum glutamic oxalacetic and glutamic pyruvic transaminases. $\mathrm{Am}$ J Clin Pathol 28(1) 56-63.

RIBEIRO, P.S., CORTEZ-PINTO, H., SOLÁ, S., CASTRO, R.E., RAMALHO, R.M., BAPTISTA, A. ET AL. 2004. Hepatocyte apoptosis, expression of death receptors, and activation of $\mathrm{NF}-\mathrm{\kappa B}$ in the liver of nonalcoholic and alcoholic steatohepatitis patients. The American journal of gastroenterology 99(9): 1708-1717.

SALAMA, A.A.A., FAYED, A.M., ATTIA, T.A., ELBATRAN, S.A., ISMAIEL, E.I., HASSAN, A. 2018. Protective Effects of Moringa oleifera extract on Isoniazid and Rifampicin Induced Hepatotoxicity in Rats: Involvement of Adiponectin and Tumor Necrosis Factor- $\alpha$. Egypt. J. Vet. Sci. 49 (1): $25-34$. 
SANKARAN, M. 2012. Protective effect of Solanum nigrum fruit extract on the functional status of liver and kidney against ethanol induced toxicity. Journal of Biochemical Technology 3(4): 339-343.

SANTHOSH, S., SINI, T.K., ANANDAN, R., MATHEW, P.T. 2007. Hepatoprotective activity of chitosan against isoniazid and rifampicin-induced toxicity in experimental rats. Eur. J. Pharmacol. 572:69-73.

SHANKER, G., SYVERSEN, T., ASCHNER, J.L., ASCHNER, M. 2005. Modulatory effect of glutathione status and antioxidants on methylmercury-induced free radical formation in primary cultures of cerebral astrocytes. Brain Res. Mol. Brain Res. 137, 11-22.

SHIH, T.Y., HO, S.C., HSIONG, C.H., HUANG, T.Y., HU, O.Y. 2013. Selected pharmaceutical excipient prevent isoniazid and rifampicin induced hepatotoxicity. Curr Drug Metab. 14(6):720-8.

SHIVAKUMAR, S.P. AND VIDYASAGAR, G.M. 2013. Ethnomedicinal plants used in the treatment of skin diseases in Hyderabad Karnataka region, Karnataka, India, Asian Pacific Journal of Tropical Biomedicine 3(11): 882-886.

SON, Y.O., KIM, J., LIM, J.C., CHUNG, Y., CHUNG, G.H., LEE, J.C. 2003. Ripe fruits of Solanum nigrum L. inhibits cell growth and induces apoptosis in MCF-7 cells Food and Chemical Toxicology 41(10):1421-28.

SRIDHAR, T.M., JOSTHNA, P. AND NAIDU, C.V. 2011. Antifungal Activity, Phytochemical Analysis of Solanum nigrum (L.) - An Important Antiulcer Medicinal Plant .Journal of Ecobiotechnology, 3(7): 11-15.

STEELE MA, BURK RF, DESPREZ RM .1991. Toxic hepatitis with isoniazid and rifampin. A metaanalysis. Chest 99: 465-471.

SUBASH, K.R., RAMESH, K.S., CHARIAN, B.V., BRITTO, F., RAO, N.J., VIJAYKUMAR, S., 2011. Study of hepatoprotective activity of Solanum nigrum and Cichorium intybus. International Journal of Pharmacology 7 (4), 504-509.

SWAROOP, T.V.S.S. AND SHIVALINGE, G.K.P., 2012. Hepatotoxicity Mechanisms and its Biomarkers. International Journal of Pharmaceutical And Chemical Sciences 1 (2), 675-682.

TANG, M., POTTER, J., MEZEY, E., 2002. leptin enhance the effect of transforming growth factor beta in increasing type I collagen formation. Biochem Biophys Res Commun 297, 906-911.

TAYAL, V., KALRA, B.S., AGARWAL, S., KHURANA, N., GUPTA, U., 2007. Hepatoprotective effect of tocopherol against isoniazide and rifampicin induced hepatotoxicity in albino rat. Indian Journal of Experimental Biology 45:1031-1036.

WALTERS, M.I. AND GERARDE, H., 1970. An ultramicromethod for the determination of conjugated and total bilirubin in serum or plasma. Microchemical Journal 15(2): 231-243.

WANG, L., HUANG, Q. H., LI, Y. X., HUANG, Y. F., XIE, J. H., XU, L. Q., SU ZR, ZENG HF, CHEN, J. N. 2018. Protective effects of silymarin on triptolide-induced acute hepatotoxicity in rats.
Molecular medicine reports, 17(1), 789-800. doi:10.3892/mmr.2017.7958.

XU, A., WANG, Y., KESHAW, H., XU, L.Y., LAM, K.S.L., COOPER, G.J.S. 2003. The fat-derived hormone adiponectin alleviates alcoholic and nonalcoholic fatty liver diseases in mice. J. Clin. Invest.112:91-100.

YAMAUCHI, T., NIO, Y., MAKI, T., KOBAYASHI, M., TAKAZAWA, T., IWABU, M., OKADAIWABU, M., KAWAMOTO, S., KUBOTA, N., KUBOTA, T., ITO, Y., KAMON, J., TSUCHIDA, A., KUMAGAI, K., KOZONO, H., HADA, Y., OGATA, H., TOKUYAMA, K., TSUNODA, M., IDE, T., MURAKAMI, K., AWAZAWA, M., TAKAMOTO, I., FROGUEL, P., HARA, K., TOBE, K., NAGAI, R., UEKI, K., KADOWAKI, T. 2007. Targeted disruption of AdipoR1 and AdipoR2 causes abrogation of adiponectin binding and metabolic actions. Nat Med. 13(3):332-9.

YOKOTA, T., ORITANI, K., TAKAHASHI, I., ISHIKAWA, J., MATSUYAMA, A., OUCHI, N. ET AL. 2000. adiponectin, a novel member of soluble defense collagens, negatively regulates the growth of myelo-monocytic progenitors and the functions of macrophages. Blood 96:1723-1732.

YOUSEF, M.I., OMAR, S.A., EL-GUENDI, M.I., ABDELMEGID, L.A. 2010. Potential protective effects of quercetin and curcumin on paracetamolinduced histological changes, oxidative stress, impaired liver and kidney functions and haematotoxicity in rat. Food Chem. Toxicol. 48, 3246-3261.

YU, C.H., XU, C.F., YE, H., LI, L., LI, Y.M. 2010. Early mortality of alcoholic hepatitis: A review of data from placebo controlled clinical trials. World $J$. Gastroentrol. 16: 2435-2439.

ZAKARIA, Z.A., GOPALAN, H.K., ZAINAL, H. ET AL. 2006. Antinociceptive, anti-inflammatory and antipyretic effects of Solanum nigrum chloroform extract in animal models. Yakugaku Zasshi 126:1171-1178.

ZHANG, W., HONG, R., TIAN, T., 2013. Silymarin's Protective Effects and Possible Mechanisms on Alcoholic Fatty Liver for Rats. Biomolecules \& therapeutics 21(4): doi:10.4062/biomolther.2013.020.

ZUBAIR, M., RIZWAN, K., RASOOL, N., AFSHAN, N., SHAHID, M., AHMED V. 2011. Antimicrobial potential of various extract and fractions of leaves of Solanum nigrum International Journal of Phytomedicine, 3: 63-67.

How to cite this article:

Abdel-Hameed M.Fayed; Abeer A. A. Salama; Ismaiel E Ismaiel; Taha A. Attia; Elbatran Seham A and Azza Hassan' 2019. Protective Effects of Solanium Nigrum Methanolic Extract Against Isoniazid/ Rifampicin Induced Hepatotoxicity in Rats. Journal of Applied Veterinary Sciences, 4(2): 52-61.

DOI : https://dx.doi.org/10.21608/javs.2019.63436 